DOI: $10.20472 /$ IAC.2019.045.039

\author{
ABHISEK SUR \\ INDIAN INSTITUTE OF MANAGEMENT RANCHI, India \\ AMARENDU NANDY \\ INDIAN INSTITUTE OF RANCHI, India \\ PARTHA RAY \\ INDIAN INSTITUTE OF MANAGEMENT CALCUTTA, India
}

\title{
CORPORATE LEVERAGE, VULNERABILITY AND IMPLICATIONS FOR BANK STABILITY: FIRM LEVEL EVIDENCE FROM INDIA
}

\begin{abstract}
:
Since the early 2000 s overseas borrowing by Indian corporates has gained prominence and has emerged as one of the principal channels of debt flows, changing the pattern of corporate leverage in India. Consistent with the trend in other EMEs, foreign currency borrowing by Indian corporates have assumed prominence, aided primarily by the steady liberalization of the capital account on the one hand and higher international liquidity, on the other hand, leading to a sustained increase in leverage of Indian corporates.

This paper analyzes the trends and consequences of corporate leverage of a sample of 825 non-financial firms that have borrowed consistently form international capital markets during 2004 and 2017. In particular, employing the Arellano Bond dynamic GMM technique, it investigates the changing contours of corporate vulnerability arising from the rising leverage and foreign currency debt of these corporates. Further, this paper investigates whether the vulnerabilities in the real sector of the economy get spill over to the financial sector, impairing the asset quality of the Indian banks.

The findings of the study indicate that higher leverage of the firms has increased the vulnerability of these firms over time, particularly in the post-global financial crisis period, and that firms' distress increased with higher foreign borrowings. Further, it was also evident that bigger firms were more distressed compared to the smaller size firms, profitable firms were less vulnerable, and that export earning of firms were inadequate to provide a buffer in case of a sudden depreciation of the Indian rupee and could render these firms vulnerable to default. The results of the study also indicated that corporate default (of distressed firms), would erode the Indian banks' asset quality increasing the stress in the banking system.

Hedging, whether through natural hedges or financial instruments will be key to protect firms with foreign currency borrowing against severe currency fluctuations. Strengthening macroeconomic fundamentals, together with close monitoring of foreign currency leverage and stricter credit appraisals by banks' is critical for reviving growth in the real sector and boosting the banking sector fundamentals.
\end{abstract}

\section{Keywords:}

Foreign Currency Borrowing, Corporate Vulnerability, Bank Asset Quality, India

JEL Classification: E44, F40, G01 